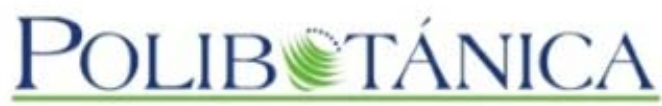

\title{
Polibotánica
}

ISSN electrónico: 2395-9525

polibotanica@gmail.com

Instituto Politécnico Nacional

México

http://www.polibotanica.mx

\section{FREQUENCY AND GENETIC VARIABILITY OF Fusarium oxysporum MATING TYPES}

\section{FRECUENCIA Y VARIABILIDAD GENÉTICA DE LOS TIPOS DE APAREAMIENTO EN Fusarium oxysporum}

\begin{abstract}
Valadez-Moctezuma, E., S. Samah y M. Frausto-Romo FREQUENCY AND GENETIC VARIABILITY OF Fusarium oxysporum MATING TYPES FRECUENCIA Y VARIABILIDAD GENÉTICA DE LOS TIPOS DE APAREAMIENTO EN Fusarium oxysporum
\end{abstract}

\section{POLIBETÁNICA}

Instituto Politécnico Nacional
Núm. 50: 31-46 México. Agosto 2020

DOI: $10.18387 /$ polibotanica.50.3

(c) (i) (2) Este es un artículo de acceso abierto bajo la licencia Creative Commons 4.0 EY NC SA Atribución-No Comercial (CC BY-NC 4.0 Internacional). 


\section{FREQUENCY AND GENETIC VARIABILITY OF Fusarium oxysporum MATING TYPES}

\section{FRECUENCIA Y VARIABILIDAD GENÉTICA DE LOS TIPOS DE APAREAMIENTO EN Fusarium oxysporum}

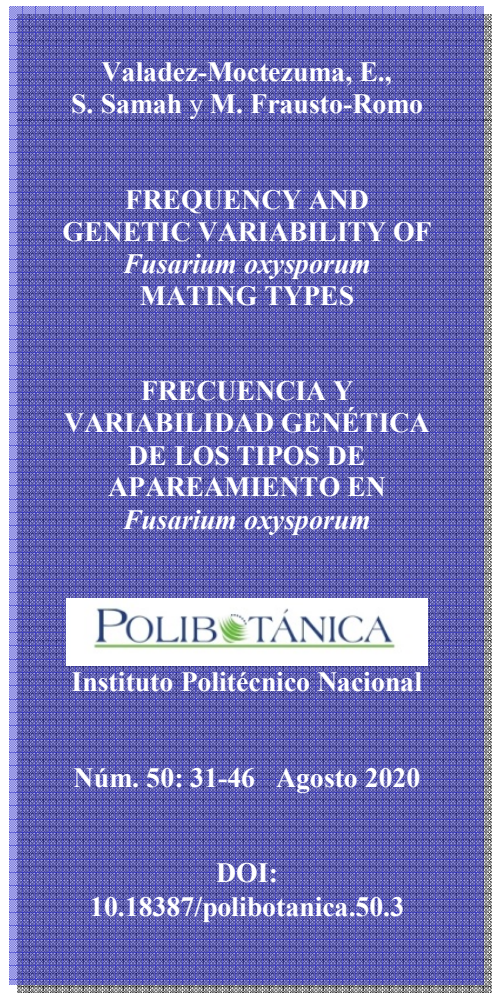

\author{
E.Valadez-Moctezuma / evaladezm@chapingo.mx \\ Laboratorio de Biología Molecular \\ Departamento de Fitotecnia, Universidad Autónoma Chapingo \\ Carretera Federal México-Texcoco Km 38.5, 56230 Texcoco, Méx \\ S. Samah \\ BIOGENETIX-LAB \\ Blvd. Acozac 9, Ixtapaluca, Estado de México, CP 56585, México \\ M. Frausto-Romo \\ Laboratorio de Biología Molecular \\ Departamento de Fitotecnia, Universidad Autónoma Chapingo \\ Carretera Federal México-Texcoco Km 38.5, 56230 Texcoco, Méx.
}

RESUMEN: El género Fusarium comprende una gran cantidad de especies cosmopolitas, muchas de las cuales son patógenos importantes de cultivos de interés agronómico. El análisis molecular de los genes del tipo de apareamiento (MAT) es una herramienta útil para estudiar los estilos de vida reproductivos y las relaciones entre especies. El objetivo de la presente investigación fue determinar el tipo de idiomorfos de MAT (MAT1-1 y/o MAT1-2) en aislados de Fusarium oxysporum, F. nygamai, F. thapsinum y $F$. verticillioides obtenidos de 20 sitios distribuidos en la zona central de México afectando cultivos de trigo y de garbanzo, y evaluar su variabilidad de secuencias. Las reacciones de PCR de 110 aislados revelaron que 66 presentaron el idiomorfo $M A T 1-1$ y 44 presentaron el idiomorfo $M A T 1-2$, pero ningún aislado mostró ambos idiomorfos. Los idiomorfos MAT1-1 y MAT1-2, de diferentes o de la misma especie de Fusarium, coincidieron en el mismo campo de cultivo de varios sitios. Las secuencias seleccionadas de los dos idiomorfos mostraron mayor divergencia entre especies que dentro de la misma especie. Estos cambios fueron mayores en las regiones no codificantes que en las regiones codificantes. La variación de los genes de tipo de apareamiento y la coexistencia de ambos idiomorfos en el mismo sitio agrícola, apuntan a un posible futuro cambio en la virulencia de los aislados de Fusarium. En general, estos hallazgos ayudarán a comprender mejor la variabilidad genética de algunas especies de Fusarium en México.

Palabras clave: Garbanzo, Idiomorfos, MAT1-1, MAT1-2, Trigo.

ABSTRACT: The genus Fusarium comprises a vast number of cosmopolitan species, many of which are important pathogens of crops of agronomic interest. Molecular analysis of mating type (MAT) genes is a useful tool to study reproductive lifestyles and relationships between species. The aim of the present research was to determine the type of MAT idiomorphs (MAT1-1 and/or MAT1-2) in Fusarium oxysporum, F. nygamai, $F$. thapsinum and $F$. verticillioides isolates obtained across 20 sites distributed in the central zone of Mexico affecting wheat and chickpea crops, and to evaluate their sequences variability. PCR reactions from 110 isolates revealed that 66 Fusarium isolates presented the MATI-1 idiomorph and 44 isolates presented the MAT1-2 idiomorph, but no isolate showed both idiomorphs. MAT1-1 and MAT1-2 
idiomorph, from the same or different Fusarium species, coincided in the same field of several sites. Selected sequences of both idiomorphs showed greater divergence between species than within the same species. These changes were greater in the noncoding regions than in the coding regions. The variation of the mating type genes and the coexistence of both idiomorphs in the same agricultural site, point to a potential future change in the virulence of Fusarium isolates. In general, these findings will help to better understand the genetic variability of some Fusarium species in Mexico.

Key words: Chickpea, Idiomorphs, MAT1-1, MAT1-2, Wheat.

\section{INTRODUCTION}

Fusarium (Ascomycota, Fungi) comprises many species with a wide geographic distribution, whose divergence dates back to about 91.3 million years ago (Ma, et al., 2013), and which have a large number of biological properties (Geiser, et al., 2013). While some species are used for enzymatic preparation for industrial application, others cause serious diseases in many crops of agronomic importance (Waalwijk, et al., 2017). These fungi are also producers of mycotoxins such as trichothecenes and fumonisins, which contaminate agricultural products and make them unsuitable for consumption (Leslie, Zeller, Lamprecht, Rheeder, \& Marasas, 2005). Fusarium oxysporum is probably the most commonly encountered species of Fusarium, and ranked fifth in the top 10 list of plant pathogenic fungi (Dean, et al., 2012). This soil-borne asexual fungus includes both pathogenic (plants and animals, including humans) and non-pathogenic strains that display a complex phylogenetic structure of cryptic species (Lombard, Sandoval-Denis, Lamprecht, \& Crous, 2019). Isolates of $F$. oxysporum can cause wilting or root rot in a wide range of host plants, among which are many crops of economic importance (Gordon \& Martyn, 1997). Fusarium verticillioides Sacc. Nirenberg, a fungus of ubiquitous distribution, is the most common species of Fusarium that affects corn. This hemibiotrophic species causes rotting of spikes, stems, and roots. It produces a broad spectrum of carcinogenic and teratogenic mycotoxins that reduce grain quality and affect human and animal health (Madania, Altawil, Naffaa, Volker, \& Hawat, 2013; Covarelli, et al., 2012). Fusarium nygamai L.W. Burgess \& Trimboli causes stem rot of the sorghum. It is also a major producer of toxins and can produce high levels of fumonisins (Leslie, Zeller, Lamprecht, Rheeder, \& Marasas, 2005). Fusarium thapsinum Klittich et al. is the most important fungus causing stem rot and the mold of the sorghum grain. These diseases are common for this crop in most of the areas where it is grown; this species is morphologically very close to $F$. verticillioides (Summerell, et al., 2011).

Many fungi, including a large number of plant pathogens, are known to propagate clonally or only rarely undergo sexual recombination (Taylor, Hann-Soden, Branco, Sylvain, \& Ellison, 2015). The sexual phase is unknown for more than 15,000 species of fungi, many of which are important phytopathogens (Arie, et al., 2000). Even in the absence of sexual recombination, fungal crop pathogens can exhibit sufficient genetic diversity to allow them to rapidly overcome new host resistances or evolve resistance against new fungicides (McDonald \& Stukenbrock, 2016). Fusarium produces both sexual and asexual species where only $20 \%$ of the species have a known sexual phase (Ma, et al., 2013). In ascomycetes, the mating type locus (MAT) has a crucial role to develop the ability to mate (Kerényi, Moretti, Waalwijk, Oláh, \& Hornok, 2004; Turgeon, 1998; Coppin, Debuchy, Arnaise, \& Picard, 1997). By convention, the idiomorphs are called MAT1-1 and MAT1-2 (Turgeon \& Yoder, 2000). The term "idiomorphic alleles" refer to the fact that these "alleles" have no significant similarity between their DNA sequences and encoded proteins, but they are in the same locus in homologous chromosomes. In heterothallic fungi, the sexual cycle is initiated when isolates of opposite mating types interact, that is, isolates that contain the idiomorph MAT1-1 with those that possess MAT1-2. In the ascomycetes, the functions of the MAT genes have generally been considered as those responsible for the regulation that governs the expression of genes involved in the mating process; this includes transcription factors involved in the expression of specific proteins that give the cell its identity with respect to the mating type (Waalwijk, et al., 2006). The 
composition of genes in the MAT locus can vary dramatically between species, but in filamentous ascomycetes, there are two genes that are constant: MAT1-1 always contains a gene called MAT1-1-1, which encodes a protein homologous to MAT1-1 in Saccharomyces cerevisiae. This protein has a unique motif called the $\alpha$-box. MAT1-2 always contains a gene called MAT1-2-1 that encodes a protein with a DNA binding domain of the high mobility group (High Mobility Group, HMG) (Martin, Wingfield, Wingfield, \& Steenkamp, 2011). In homothallic (self-fertile) ascomycetes, sexual reproduction can occur between any two individuals. These species are homologous for the MAT1-1-1 and MAT1-2-1 genes in the same genome organized in a species-specific manner, and generally more closely linked (Glass \& Smith, 1994).

Molecular analysis of mating type genes is a useful tool for the research of reproductive lifestyles, as well as species relationships and research of various aspects of molecular evolution (Martin, Wingfield, Wingfield, \& Steenkamp, 2011). Furthermore, knowledge of the mode of reproduction is important for the design of successful control strategies, since these are different for clonal and sexual reproductive organisms (Waalwijk, et al., 2017). The purposes of this study were: (1) to determine the type of MAT idiomorphs in Fusarium oxysporum, $F$. nygamai, $F$. thapsinum and $F$. verticillioides isolated from wheat and chickpea plants cultivated in several sites distributed in the central region of Mexico, (2) to estimate the frequency of mating types by species and by sites, (3) and to estimate the changes in sequences of MAT1-1 and MAT1-2 genes among and between species. It is not expected to find both idiomorphs in the same Fusarium isolate, since the four species considered here were previously reported heterothallic. Furthermore, high diversity in mating type sequences is expected due to the total number of isolates studied, the 20 sites sampled, and the provenance of the isolates from two crops.

\section{MATERIAL AND METHODS}

\section{Fungal isolates}

Fifty-nine isolates of Fusarium oxysporum were obtained from chickpea (Cicer arietinum L.) plants with wilting and/or yellowing symptoms, cultivated in the states of Michoacán, Guanajuato and Sonora, in Mexico (Luna-Paez, Silva-Rojas, Marbán-Mendoza, \& ValadezMoctezuma, 2004). Another 51 isolates of Fusarium spp. were obtained from wheat (Triticum aestivum) plants with fusariosis and cultivated in the state of Guanajuato, Mexico (RangelCastillo, Valadez-Moctezuma, \& Lozoya-Saldaña, 2017). These isolates (Supplementary Table $\mathrm{S} 1$ ) were maintained by regular subculture on potato dextrose agar (PDA) at $27{ }^{\circ} \mathrm{C}$, and stored as spore suspension or mycelium in $100 \%$ glycerol at room temperature. The isolates were previously purified by hyphae tip developed in PDA medium and were incubated at $27^{\circ} \mathrm{C}$. The fungal mycelia were collected with a spatula from the culture medium. The molecular identification of Fusarium isolates were carried out during different steps using sequences of the translation elongation factor 1- $\alpha$ (EF1- $\alpha$; primers EF-1 5'ATGGGTAAGGA (A/G)GACAAGAC 3' and EF-2 5' GGA(G/A)GTACCAGT(G/C)ATCATGTT 3' (O'Donnell, Kistler, Cigelnik, \& Ploetz, 1998a)), small subunit ribosomal RNA gene (primers NMS1 5', CAGCAGTGAGGAATATTGGTCAATG 3' and NMS2 5' GCGGATCATCGAATTAAATAACAT 3' (Li, Rouse, \& German, 1994)) and/or MAT genes (primers are mentioned below). Species identification (Supplementary Table S1) was made by comparison of the sequences against the databases via the Basic Local Alignment Search Tool (Blast, https://blast.ncbi.nlm.nih.gov/Blast.cgi).

\section{DNA extraction and identification of the mating type}

The total DNA of the harvested mycelium was extracted using the cetyltrimethylammonium bromide (CTAB) method, based on Doyle \& Doyle (1987). The DNA quality was determined in $1 \%$ agarose gel electrophoresis and quantified by spectrophotometry (ND-1000 Thermo scientific, USA). The presence of the mating type of the 110 isolates was determined by PCR 
amplification using two primer pairs: FoM1-1-1 (5' GCTTGATCTGTTCGGTCATG 3')/FoM1-1-2 (5' GCTGCTGCATCTTGGATTGC 3') for MAT1-1 and FoM2-1-1 (5', ACATATCGATAGCATCTACC 3')/FoM2-1-2 (5' AGGCGGTAATCTGCTGTGTA 3') for MAT1-2 (Yun, Arie, Kaneko, Yoder, \& Turgeon, 2000). The reaction mixture was composed of $200 \mu \mathrm{M}$ of each dNTP, $1.5 \mathrm{U}$ of Taq DNA polymerase (PROMEGA, Madison, WI, USA), 1× of Taq buffer, $2.5 \mathrm{mM}$ of $\mathrm{MgCl}_{2}, 100 \mathrm{ng}$ of DNA, and $0.3 \mu \mathrm{M}$ of each primer in a final volume of $25 \mu \mathrm{L}$. The thermocycling conditions consisted of an initial denaturation at $94{ }^{\circ} \mathrm{C}$ for $10 \mathrm{~min}$, 30 cycles $\left[94^{\circ} \mathrm{C}\right.$ for $1 \mathrm{~min} ; 53{ }^{\circ} \mathrm{C}$ for $1 \mathrm{~min} ; 68^{\circ} \mathrm{C}$ for $2 \mathrm{~min}$ ] and a final extension cycle of 72 ${ }^{\circ} \mathrm{C}$ for $10 \mathrm{~min}$. The amplified fragments were separated in $1.2 \%$ agarose and visualized by UV light after staining with ethidium bromide.

\section{Amplicon sequencing and cluster analysis}

The PCR products of the MAT1-1 and MAT1-2 genes were sequenced in both directions using the same primers as in PCR reactions. To determine the genetic diversity and the changes in nucleotide bases and amino acids in the two idiomorphs (MAT1-1 and MAT1-2), 60\% of the obtained PCR products were sequenced, i.e. 40 isolates with MAT1-1 and 26 with MAT1-2. By species, 51 isolates of $F$. oxysporum (31with MAT1-1 and 20 with MAT1-2), nine isolates of $F$. nygamai (three MAT1-1 and six MAT1-2), four isolates of $F$. thapsinum (all MAT1-1), and two isolates of $F$. verticillioides (both $M A T 1-1$ ) were analyzed. The raw sequences were edited, and the consensus sequences were obtained using BioEdit 7.1.3.0 software (Hall, 1999). The sequences were compared and deposited (accession number is shown in Supplementary Table $\mathrm{S} 1$ ) in the GenBank database (http://www.ncbi.nlm.nih.gov/). The nucleotide sequences and their translated amino acids were aligned using the ClustalW tool implemented in MEGA6 (Tamura, Stecher, Peterson, Filipski, \& Kumar, 2013). The two MAT idiomorphs were analyzed separately for cluster analysis, using nucleotide sequences or amino acid sequences as input data. The most appropriate nucleotide substitution model (Jones-Taylor-Thornton model) was determined using the tool implemented in MEGA6 (Tamura, Stecher, Peterson, Filipski, \& Kumar, 2013). The Maximum likelihood and Neighbor-Joining based phylogenetic methods were employed using MEGA6, and internal branches were evaluated for 500 bootstrap replicates.

\section{RESUlTS}

\section{Determination of mating type}

The PCR products obtained with the primer pairs FoM1-1-1/FOM-1-1-2 and FoM2-1-1/FoM-21-2 had an approximate size of $1000 \mathrm{bp}$ for MAT1-1 and $700 \mathrm{bp}$ for MAT1-2. Out of the 110 isolates studied, it was found that 66 isolates contained the MAT1-1 idiomorph and 44 isolates contained the MAT1-2 idiomorph. No isolate presented the amplification of both idiomorphs (Supplementary Table S1). By crop, out of 59 Fusarium isolates from chickpea, 41 of them contained the MAT1-1 idiomorph and 18 the MAT1-2 idiomorph; while out of the 51 fungal isolates obtained from wheat, 25 contained the MAT1-1 idiomorph and 26 contained the MAT12 idiomorph. Regarding the distribution of Fusarium isolates across the fields where they obtained, both MAT idiomorphs were coincided in eight of the 20 sites, namely Abasolo, Celaya, Penjamo, Salvatierra, Valle de Santiago and Yuriria in the state of Guanajuato, and the localities of Morelia and Singuio in Michoacán (Table 1).

\section{Variability of mating type sequences}

The MAT1-1 idiomorph sequences $(\approx 900 \mathrm{bp})$ consisted of two partial exons and one intron; while the MAT1-2 idiomorph $(\approx 600 \mathrm{bp})$ consisted of two complete introns, two partial exons and one complete exon. The multiple sequence alignment, containing the four species of Fusarium, of the 40 nucleotide sequences of the MAT1-1 idiomorph showed the presence of 108 variable sites along the alignment (12.4\% of the total alignment). Of the changes, $31.3 \%$, $11.5 \%$ and $9.7 \%$ were found in intron, exon 1 and exon 2, respectively (table 2). For the 31 sequences of $F$. oxysporum, 19 sites $(2.2 \%)$ were variable from the 869 bases in the alignment. 
Of the changes, $2.1 \%, 2.3 \%$ and $1.4 \%$ were found in intron, exon 1 and exon 2 , respectively (table 2). For the two sequences of $F$. verticillioides, 11 sites $(1.2 \%)$ were variable from the 905 bases in the alignment. Of the changes, $2.2 \%, 1.3 \%$ and $0 \%$ were found in intron, exon 1 and exon 2, respectively (table 2). For the three sequences of $F$. nygamai, only one variable site was detected in the exon 1 along 892 bases in the alignment. Meanwhile, there was no variable site detected along the alignment of 903 bases for the four sequences of $F$. thapsinum.

Table 1. Distribution of mating type idiomorphs in Fusarium species isolated from wheat and chickpea crops across the central region of Mexico.

\begin{tabular}{|c|c|c|c|}
\hline Origin & $\begin{array}{l}\text { Isolates } \\
\text { number }\end{array}$ & $\begin{array}{l}\text { MAT1-1 } \\
\text { (isoletes number and species name) }\end{array}$ & $\begin{array}{l}\text { MAT1-2 } \\
\text { (isoletes number and species name) }\end{array}$ \\
\hline Abasolo, Gto. & 4 & 2 (1 Fusarium sp. and 1 F. nygamai) & $2(1$ Fusarium sp. and $1 F$. nygamai $)$ \\
\hline Apaseo el Grande, Gto. & 1 & $1($ F. oxysporum $)$ & 0 \\
\hline Celaya, Gto. & 3 & $2(2 F$. oxysporum $)$ & 1 (F. oxysporum $)$ \\
\hline Cortazar, Gto. & 1 & $1(2 F$. oxysporum $)$ & 0 \\
\hline Cuitzeo, Mich. & 4 & $4(4$ F. oxysporum $)$ & 0 \\
\hline El Calvario, Mich. & 3 & $3(3$ F. oxysporum $)$ & 0 \\
\hline INIFAP, Mich. & 1 & $1(F$. oxysporum $)$ & 0 \\
\hline Irapuato, Gto. & 3 & $3(3$ F. oxysporum $)$ & 0 \\
\hline Juventino Rosas, Gto. & 1 & $1($ F. oxysporum $)$ & 0 \\
\hline La purisima, Mich. & 3 & $3(3$ F. oxysporum $)$ & 0 \\
\hline Morelia, Mich. & 9 & $8(8$ F. oxysporum $)$ & $1($ F. oxysporum $)$ \\
\hline Penjamo, Gto & 43 & $\begin{array}{l}19 \text { (8 Fusarium sp., } 5 \text { F. oxysporum, } \\
2 \text { F. nygamai, } \\
2 \text { F. thapsinum and } 2 \text { F. verticillioides })\end{array}$ & $\begin{array}{l}24(12 \text { Fusarium sp., } 6 \text { F. oxysporum } \\
\text { and } 6 \text { F. nygamai, } 2 \text { F. thapsinum })\end{array}$ \\
\hline Puquichapio, Gto. & 2 & $2(2 F$. oxysporum $)$ & 0 \\
\hline Salamanca, Gto. & 4 & $\begin{array}{l}4(1 \text { Fusarium } \mathrm{sp} ., 1 \text { F. oxysporum and } \\
2 \text { F. thapsinum })\end{array}$ & 0 \\
\hline Salvatierra, Gto. & 7 & $2(2$ F. oxysporum $)$ & $5(5$ F. oxysporum $)$ \\
\hline Sinaloa, Sinaloa & 4 & 0 & $4(4 F$. oxysporum $)$ \\
\hline Singuio, Mich. & 5 & $4(4$ F. oxysporum $)$ & 1 (1 F. oxysporum) \\
\hline Valle de Santiago, Gto. & 4 & $2(2$ F. oxysporum $)$ & $2(2$ F. oxysporum $)$ \\
\hline Villagran, Gto. & 1 & 0 & $1(1 F$. oxysporum $)$ \\
\hline Yuriria, Gto. & 7 & $4(4 F$. oxysporum $)$ & $3(3$ F. oxysporum $)$ \\
\hline
\end{tabular}

Gto.: Guanajuato State

Mich.: Michoacán State

The multiple alignments of the 26 nucleotide sequences of the MAT1-2 idiomorph of the two Fusarium species, i.e. F. oxysporum and F. nygamai, showed the presence of 44 variable sites along the alignment (7.5\% of the total alignment). Of the changes, $10.7 \%, 10.6 \%, 4.3 \%, 8 \%$ and $5.5 \%$ were found in intron 1 , intron 2, exon 1, exon 2 and exon 3, respectively (Table 2). For the 20 sequences of $F$. oxysporum, eight sites $(1.3 \%)$ were variable from the 631 bases in the alignment. Of the changes, $5.4 \%, 0 \%, 0 \%, 0.8 \%$ and $1.5 \%$ took place in intron 1 , intron 2 , exon 1, exon 2 and exon 3, respectively (Table 2). For the six sequences of $F$. nygamai, 15 sites $(2.5 \%)$ were variable from the 592 bases in the alignment. Of the changes, $3.6 \%, 6.4 \%, 4.3 \%$, $2.7 \%$ and $1 \%$ were found in intron 1 , intron 2, exon 1, exon 2 and exon 3 , respectively (Table 2 ). 
Table 2. Genetic variability of MAT1-1 and MAT1-2 sequences from Fusarium species.

\begin{tabular}{|l|c|c|c|c|c|c|c|c|c|c|}
\hline \multirow{2}{*}{ Mating type } & \multicolumn{4}{|c|}{ MAT1-1 } & \multicolumn{7}{c|}{ MAT1-2 } \\
No. variable sites / No. total sites & \multicolumn{7}{c|}{ No. variable sites / No. total sites } \\
\hline $\begin{array}{c}\text { Fusarium } \\
\text { species }\end{array}$ & Total & $\begin{array}{c}\text { Intron } \\
1\end{array}$ & $\begin{array}{c}\text { Exon } \\
1\end{array}$ & $\begin{array}{c}\text { Exon } \\
2\end{array}$ & Total & $\begin{array}{c}\text { Intron } \\
1\end{array}$ & $\begin{array}{c}\text { Intron } \\
2\end{array}$ & $\begin{array}{c}\text { Exon } \\
1\end{array}$ & $\begin{array}{c}\text { Exon } \\
2\end{array}$ & $\begin{array}{c}\text { Exon } \\
3\end{array}$ \\
\hline The four species & $108 / 869$ & $15 / 48$ & $86 / 749$ & $7 / 72$ & $44 / 588$ & $6 / 56$ & $5 / 47$ & $1 / 23$ & $21 / 263$ & $11 / 199$ \\
\hline F. oxysporum & $19 / 869$ & $1 / 48$ & $17 / 749$ & $1 / 72$ & $8 / 631$ & $3 / 56$ & $0 / 47$ & $0 / 66$ & $2 / 263$ & $3 / 199$ \\
\hline F. nygamai & $1 / 892$ & $0 / 46$ & $1 / 749$ & $0 / 97$ & $15 / 592$ & $2 / 56$ & $3 / 47$ & $1 / 23$ & $7 / 263$ & $2 / 203$ \\
\hline F. verticillioides & $11 / 905$ & $1 / 46$ & $10 / 749$ & $0 / 109$ & - & - & - & - & - & - \\
\hline F. thapsinum & $0 / 903$ & $0 / 46$ & $0 / 749$ & $0 / 108$ & - & - & - & - & - & - \\
\hline
\end{tabular}

Comparing the variations in the coding and non-coding regions of the MAT genes together, $17.6 \%$ of variable sites were found in the non-coding regions and $9.6 \%$ in the coding regions of the species studied. For $F$. oxysporum, 2.6\% of variable sites were found in the non-coding regions and $1.7 \%$ in the coding regions. Meanwhile, For $F$. nygamai, $3.4 \%$ of variable sites were found in the non-coding regions and $0.8 \%$ in the coding regions.

The multiple sequence alignment, containing all four species of Fusarium, of the 40 amino acid sequences of the MAT1-1 idiomorph showed the presence of 42 variable residues along the alignment (15.4\% of the total alignment). For the 31 sequences of $F$. oxysporum, 6 residues $(2.2 \%)$ were variable from the 273 amino acids in the alignment. For the two sequences of $F$. verticillioides, 6 residues $(2.1 \%)$ were variable from the 286 amino acids in the alignment. For the three sequences of $F$. nygamai, only one variable site was detected along 286 amino acids in the alignment. Meanwhile, there was no variable residue detected along the alignment of 281 amino acids for the four sequences of $F$. thapsinum. The multiple alignments of the 26 amino acid sequences of the MAT1-2 idiomorph from two Fusarium species, i.e. F. oxysporum and F. nygamai, showed the presence of 12 variable residues along the alignment $(7.5 \%$ of the total alignment). For the 20 sequences of $F$. oxysporum, two residues $(1.1 \%)$ were variable from the 175 amino acids in the alignment. For the six sequences of $F$. nygamai, 4 residues $(2.5 \%)$ were variable from the 163 amino acids in the alignment.

\section{Cluster analysis}

The obtained trees based on the nucleotides and the translated sequences showed a similar grouping pattern. All the isolates of $F$. oxysporum were grouped in a single clade apart from the isolates of the species $F$. nygamai, $F$. verticillioides and $F$. thapsinum in the tree obtained with the sequences of MAT1-1 (fig. 1) and from the species F. nygamai in the tree obtained with the MAT1-2 sequences (fig. 2). The isolates F24 (from chickpea) and T8.2 (from wheat) showed some divergence, while F7 and F67 (from chickpea) showed greater divergence from the remaining isolates of $F$. oxysporum when analyzed with MAT1-1 (fig. 1). The isolates F8, F57, F66 and F74 (from chickpea) were the most divergent of the remaining isolates of $F$. oxysporum when analyzed with MAT1-2 (fig. 2). 


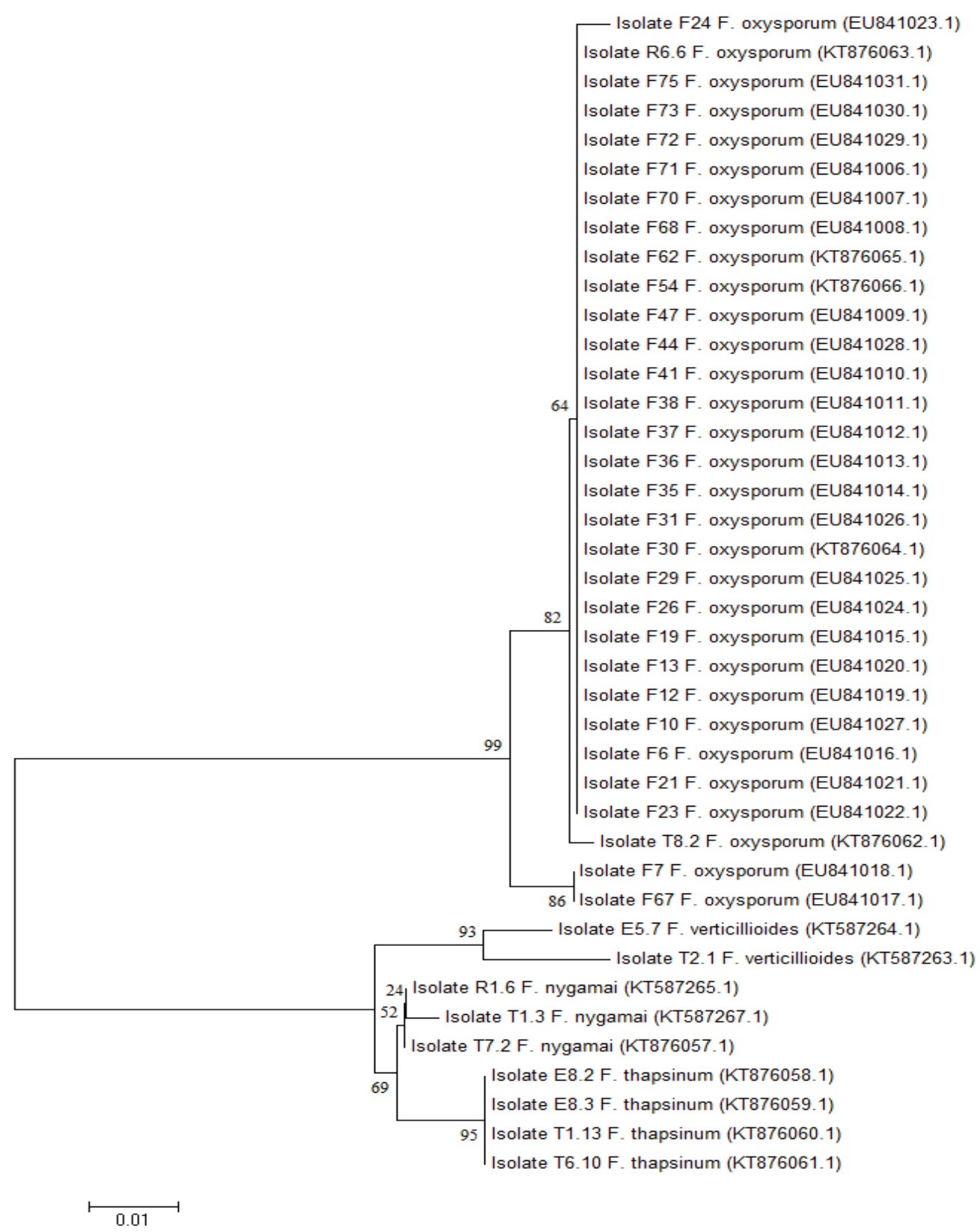

Fig. 1. Dendrogram based on amino acid sequences of the mating type MAT1-1 idiomorph for the isolates of Fusarium oxysporum, F. nygamai, $F$. verticillioides and $F$. thapsinum obtained from wheat and chickpea plants in the central region of Mexico. The Neighbor-Joining method and the Jones-Taylor-Thornton (JTT) model were applied. The numbers in the nodes represent the estimated bootstrap values from 500 repetitions. The key in parentheses indicates the reference number of the sequence in the Genbank. The isolates name initial " $F$ " indicates isolates obtained from chickpea and the initials "E", "R" and "T" indicates isolates obtained from wheat. 


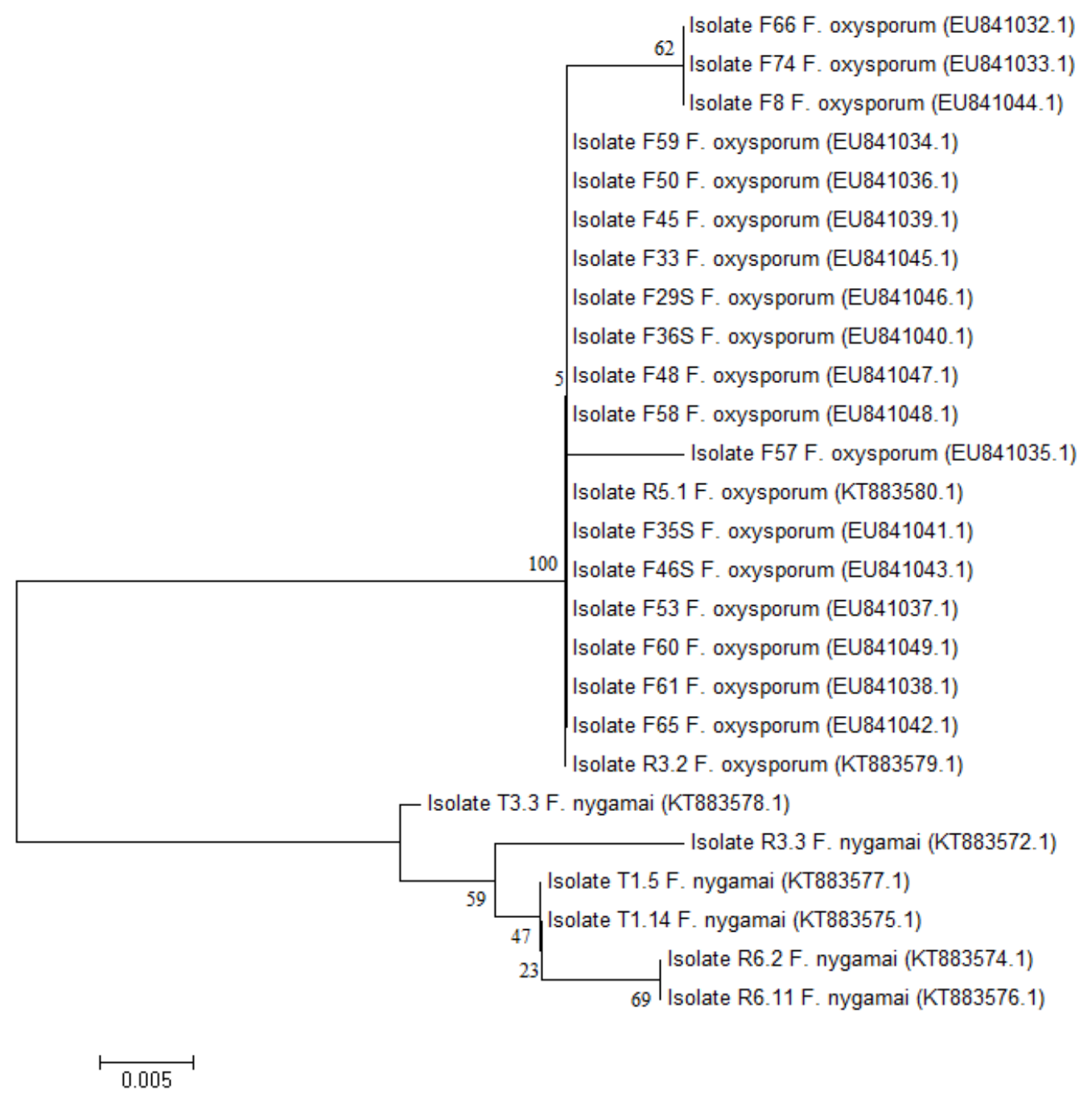

Fig. 2. Dendrogram based on amino acid sequences of the mating type MAT1-2 idiomorph for the isolates of Fusarium oxysporum and F. nygamai obtained from wheat and chickpea plants in central Mexico. The Neighbor-Joining method and the Jones-Taylor-Thornton (JTT) model were applied. The numbers in the nodes represent the estimated bootstrap values from 500 repetitions. The key in parentheses indicates the reference number of the sequence in the Genbank. The isolates name initial "F" indicates isolates obtained from chickpea and the initials " $R$ " and " $T$ " indicates isolates obtained from wheat.

\section{DISCUSSION}

Using a molecular approach, it is possible to detect MAT genes also in asexual species, which is a first step towards learning the causes of asexuality (Yun, Arie, Kaneko, Yoder, \& Turgeon, 2000). In the genomes of species that reproduce asexually, sequences responsible for inheritance of the type of mating were detected; even, the examined isolates of $F$. oxysporum and $F$. nygamai showed differentiation in the genetic background of the mating type. No isolate showed both idiomorphs, which is a distinctive feature of the heterothallic species. Similar results were reported for several species from the genus Fusarium (Ma, et al., 2013; Irzykowska \& Kosiada, 2011; Fourie, Steenkamp, Gordon, \& Viljoen, 2009; Kawabe, et al., 2005). For the species $F$. verticillioides and $F$. thapsinum, which are known to be heterothallic 
(Martin, Wingfield, Wingfield, \& Steenkamp, 2011), only the presence of the MAT1-1 idiomorph was detected, probably due to the limited number of isolates studied, i.e. 2 and 4 isolates, respectively (species identification by sequencing).

The designation of the mating type to each Fusarium isolate is shown in Supplementary Table $\mathrm{S} 1$. The results revealed the presence of only one mating type in each $F$. oxysporum isolate, with a total of $60.8 \%$ MAT1-1 and 39.2\% MAT1-2 within the isolates evaluated. Similar results were reported by Kashyap, Rai, Kumar, \& Srivastava (2016) where they determined that $60 \%$ of the isolates were MAT1-1 and 40\% MAT1-2 in 20 isolates of F. oxysporum $\mathrm{f}$. sp. ciceris. Irzykowska \& Kosiada (2011) found that from a total of 30 isolates of $F$. oxysporum, 33\% contained MAT1-1 and 77\% contained MAT1-2. While, Kawabe, et al. (2005) found that $76.7 \%$ contained MAT1-1 and 23.3\% contained MAT1-2, from a total of 30 isolates of $F$. oxysporum $\mathrm{f}$. sp. lycopersici. These values may vary depending on the number of isolates analyzed, geographic zones, and type and number of host species (Waalwijk, et al., 2006).

The multiple sequence alignments of the MAT genes of Fusarium species showed a greater divergence between species than within the same species. The four species together presented polymorphisms in $12.4 \%$ of their MAT1-1 sequences, whereas the isolates of $F$. oxysporum, $F$. verticillioides, $F$. nygamai and $F$. thapsinum varied only by $2.2 \%, 1.2 \%, 0.1 \%$, and $0 \%$, respectively. For $M A T 1-2$, the isolates of $F$. oxysporum varied in $1.3 \%$ of their sequences and $F$. nygamai in $2.5 \%$, while the divergence between the two species was higher (7.5\%). These results agree with previous reports where it has been found that mating type genes are highly divergent between species (Wik, Karlsson, \& Johannesson, 2008; Arie, Christiansen, Yoder, \& Turgeon, 1997) and can be strongly conserved within species (Turgeon, 1998). Moreover, intraspecific variability is common in $F$. oxysporum despite their sexual form is unknown (Irzykowska \& Kosiada, 2011; O’Donnell, Ward, Geiser, Kistler, \& Aoki, 2004). Changes in non-coding regions of MAT genes in Fusarium species, namely $F$. oxysporum and $F$. nygamai were greater than in the coding regions. Martin, Wingfield, Wingfield, \& Steenkamp (2011) indicated that, in general, the non-coding portions of the $M A T$ loci are more variable among the species than the coding portions. The heterothallic $M A T$ loci do not recombine and all the parts are strongly linked. As a result, the non-coding regions of the heterothallic $M A T$ loci are not independent and could diverge more rapidly due to the functional restriction acting on the linked coding regions; and selection against the accumulation of deleterious mutations in $M A T$ loci may sometimes be lacking (Clark, Aagaard, \& Swanson, 2006).

Cluster analyses of the DNA and amino acid sequences derived from the coding region in the two MAT idiomorphs revealed that all the isolates of $F$. oxysporum were grouped together in a single clade separated from the isolates of the species $F$. nygamai, $F$. verticillioides and $F$. thapsinum (figs. 1 and 2), confirming greater divergence between species than within the same species. Taxonomically, the species $F$. nygamai, $F$. verticillioides and $F$. thapsinum belong to the Gibberella fujikuroi species complex, African clade, a taxonomic group close to $F$. oxysporum complex (Geiser, et al., 2013; Martin, Wingfield, Wingfield, \& Steenkamp, 2011; O’Donnell, Cigelnik, \& Nirenberg, 1998b).

Although functional mating type genes have been identified (Martin, Wingfield, Wingfield, \& Steenkamp, 2011; Arie, et al., 2000), the crossbreeding of F. oxysporum f. sp. lycopersici or $\mathrm{f}$. sp. cubense of opposite mating types did not result in viable offspring (Fourie, Steenkamp, Gordon, \& Viljoen, 2009; Kawabe, et al., 2005). Alternative mechanisms that potentially lead to genetic recombination are parasexual fusion or horizontal gene transfer. Although the mechanisms involved are not yet clear, there are examples of gene transfer across different phylogenetic boundaries at various taxonomic levels (Friesen, Faris, Solomon, \& Oliver, 2008; Khaldi, Collemare, Leburn, \& Wolfe, 2008). However, in the case of $F$. oxysporum, the exchange of genetic material through the direct transfer of genes from one fungal isolate to another would be limited by vegetative incompatibility (Lievens, Houterman, \& Rep, 2009; Lievens et al., 2009). However, in an ascomycete fungus, Colletotrichum gloeosporioides, the 
transfer of a chromosome in laboratory conditions between vegetative incompatible isolates has been reported (He, Rusu, Poplawski, Irwin, \& Manners, 1998), showing that, under certain conditions, the genetic material can be exchanged between vegetative compatibility groups.

Although many species of Fusarium are asexual (Fourie, Steenkamp, Gordon, \& Viljoen, 2009; Arie, et al., 2000), the fact of determining the presence of both MAT1-1 and MAT1-2 idiomorphs from one species in the same sites namely Abasolo, Celaya, Penjamo, Salvatierra, Valle de Santiago and Yuriria in the state of Guanajuato, and the localities of Morelia and Singuio in Michoacán, increases the potential for possible genetic recombination among isolates, resulting in more aggressive and pathogenic Fusarium isolates, thus demanding more efficient strategies for crop protection.

\section{CONCLUSION}

Of the 110 Fusarium isolates studied, $60 \%$ of the isolates contained MAT1-1 and $40 \%$ contained the MAT1-2 idiomorph, and none isolate showed both idiomorphs, Furthermore, the nucleotides and amino acid sequences of MAT genes showed more divergence between than within species. The variation of the mating type genes and the coexistence of the two idiomorphs in the same agricultural site, point to a potential future change in the aggressiveness and pathogenicity of Fusarium isolates. These results will help to better understand the genetic diversity of some Fusarium species, especially $F$. oxysporum.

\section{LITERATURE CITED}

Arie, T., Christiansen, S. K., Yoder, O. C., \& Turgeon, B. G. (1997). Efficient cloning of ascomycete mating type genes by PCR amplification of the conserved MAT HMG Box. Fungal Genetics and Biology, 21(1), 118-130. https://doi.org/10.1006/fgbi.1997.0961

Arie, T., Kaneko, I., Yoshida, T., Noguchi, M., Nomura, Y., \& Yamaguchi, I. (2000). MatingType Genes from Asexual Phytopathogenic Ascomycetes Fusarium oxysporum and Alternaria alternata. Molecular Plant-Microbe Interactions, 13(12), 1330-1339. https://doi.org/10.1094/MPMI.2000.13.12.1330

Clark, N. L., Aagaard, J. E., \& Swanson, W. J. (2006). Evolution of reproductive proteins from animals and plants. Reproduction, 131,11-22. https://doi.org/10.1530/rep.1.00357

Coppin, E., Debuchy, R., Arnaise, S., \& Picard, M. (1997). Mating types and sexual development in filamentous ascomycetes. Microbiology and Molecular Biology Reviews, 61(4), 411-428.

Covarelli, L., Stifano, S., Becarri, G., Raggi, L., Lattanzio, V. M., \& Albertini, E. (2012). Characterization of Fusarium verticillioides strains isolated from maize in Italy: Fumonisin production, pathogenicity and genetic variability. Food Microbiology, 31(1), 17-24. https://doi.org/10.1016/j.fm.2012.02.002

Dean, R., Van Kan, J. A., Pretorious, Z. A., Hammond-Kosack, K. E., Di Pietro, A., Spanu, P. D., . . . Foster, G. D. (2012). The Top 10 fungal pathogens in molecular plant pathology. Molecular Plant Pathology, 13(4), 414-430. https://doi.org/10.1111/j.13643703.2011.00783.x

Doyle, J. J., \& Doyle, J. L. (1987). A rapid DNA isolation procedure for small quantities of fresh leaf tissue. Phytochemistry Bulletin, 19(1), 11-15.

Fourie, G., Steenkamp, E. T., Gordon, T. R., \& Viljoen, A. (2009). Evolutionary relationships among the Fusarium oxysporum f. sp. cubense vegetative compatibility groups. Applied and Environmental Microbiology, 75(14), 4770-4781. https://doi.org/10.1128/AEM.00370-09

Friesen, T. L., Faris, J. D., Solomon, P. S., \& Oliver, R. P. (2008). Host-specific toxins: effectors of necrotrophic pathogenicity. Cellular Microbiology, 10(7), 1421-1428. https://doi.org/10.1111/j.1462-5822.2008.01153.x 
Geiser, D. M., Aoki, T., Bacon, C. W., Baker, S. E., Bhattcharyya, M. K., Brandt, M. E., . . . Zhang, N. (2013). One Fungus, One Name: Defining the Genus Fusarium in a Scientifically Robust Way That Preserves Longstanding Use. Phytopathology, 103(5), 400-408. https://doi.org/10.1094/PHYTO-07-12-0150-LE

Glass, L. N., \& Smith, M. L. (1994). Structure and function of a mating-type gene from the homothallic species Neurospora africana. Molecular and General Genetics, 244, 401409. https://doi.org/10.1007/BF00286692

Gordon, T. R., \& Martyn, R. D. (1997). The evolutionary biology of Fusarium oxysporum. Annual Review of Phytopathology, 35, 111-128. https://doi.org/10.1146/annurev.phyto.35.1.111

Hall, T. A. (1999). BioEdit: a user-friendly biological sequence editor and analysis program for windows 95/98/NT. Nucleic Acids Symposium Series, 41, 95-98.

He, C., Rusu, A. G., Poplawski, A. M., Irwin, J. A., \& Manners, J. M. (1998). Transfer of a supernumerary chromosome between vegetatively incompatible biotypes of the fungus Colletotrichum gloeosporioides. Genetics, 150(4), 1459-1466.

Irzykowska, L., \& Kosiada, T. (2011). Molecular identification of mating type genes in asexually reproducing Fusarium oxysporum and F. culmorum. Journal of Plant Protection Research, 51(4), 405-409. https://doi.org/10.2478/v10045-011-0066-0

Kashyap, P. L., Rai, S., Kumar, S., \& Srivastava, A. K. (2016). Genetic diversity, mating types and phylogenetic analysis of Indian races of Fusarium oxysporum f. sp. ciceris from chickpea. Archives of Phytopathology and Plant Protection, 49, 533-553. https://doi.org/10.1080/03235408.2016.1243024

Kawabe, M., Kobayashi, Y., Okada, G., Yamaguchi, Y., Teraoka , T., \& Arie, T. (2005). Three evolutionary lineages of tomato wilt pathogen, Fusarium oxysporum f. sp. lycopersici, based on sequences of $I G S, M A T 1$, and $p g 1$, are each composed of isolates of a single mating type and a single or closely related vegetative compatibility group. Journal of General Plant Pathology, 71, 263-272. https://doi.org/10.1007/s10327-005-0203-6

Kerényi, Z., Moretti, A., Waalwijk, C., Oláh, B., \& Hornok, L. (2004). Mating Type Sequences in Asexually Reproducing Fusarium Species. Applied and Environmental Microbiology, 70(8), 4419-4423. https://doi.org/10.1128/AEM.70.8.4419-4423.2004

Khaldi, N., Collemare, J., Leburn, M.-H., \& Wolfe, K. H. (2008). Evidence for horizontal transfer of a secondary metabolite gene cluster between fungi. Genome Biology, 9, R18. https://doi.org/10.1186/gb-2008-9-1-r18

Leslie, J. F., Zeller, K. A., Lamprecht, S. C., Rheeder, J. P., \& Marasas, W. F. (2005). Toxicity, Pathogenicity, and Genetic Differentiation of Five Species of Fusarium from Sorghum and Millet. Phytopathology, 95(3), 275-283. https://doi.org/10.1094/PHYTO-95-0275

Li, K. N., Rouse, D. I., \& German, T. L. (1994). PCR primers that allow intergeneric differentiation of ascomycetes and their application to Verticillium spp. Applied and Environmental Microbiology, 60(12), 4324-4331.

Lievens, B., Houterman, P. M., \& Rep, M. (2009). Effector gene screening allows unambiguous identification of Fusarium oxysporum f. sp. lycopersici races and discrimination from other formae speciales. FEMS Microbiology Letters, 300(2), 201-215. https://doi.org/10.1111/j.1574-6968.2009.01783.x

Lombard, L., Sandoval-Denis, M., Lamprecht, S. C., \& Crous, P. W. (2019). Epitypification of Fusarium oxysporum - clearing the taxonomic chaos. Persoonia - Molecular Phylogeny avolution of Fungi, 43, 1-47. https://doi.org/10.3767/persoonia.2019.43.01

Luna-Paez, A., Silva-Rojas, H. V., Marbán-Mendoza, N., \& Valadez-Moctezuma, E. (2004). Variabilidad genética de Fusarium oxysporum Schlechtend.:Fr. f. sp. ciceris (Padwick) Matuo y K. Sato mediante PCR-RAPD's en el Bajío, México. Revista Mexicana de Fitopatología, 22, 44-51.

Recibido:

26/febrero/2020

Aceptado:

27/julio/2020 
Madania, A., Altawil, M., Naffaa, W., Volker, P. H., \& Hawat, M. (2013). Morphological and Molecular Characterization of Fusarium Isolated From Maize in Syria. Journal of Phytopathology, 161, 452-458. https://doi.org/10.1111/jph.12085

Martin, S. H., Wingfield, B. D., Wingfield, M. J., \& Steenkamp, E. T. (2011). Structure and evolution of the Fusarium mating type locus: new insights from the Gibberella fujikuroi complex. Fungal Genetics and Biology, 48(7), 731-740. https://doi.org/10.1016/j.fgb.2011.03.005

McDonald, B. A., \& Stukenbrock, E. H. (2016). Rapid emergence of pathogens in agroecosystems: global threats to agricultural sustainability and food security. Philosophical transactions of the Royal Society of London. Series B, Biological sciences, 371, 20160026. https://doi.org/10.1098/rstb.2016.0026

O’Donnell, K., Cigelnik, E., \& Nirenberg, H. I. (1998b). systematic and phylogeography of the Gibberella fujikuroi species complex. Mycologia, 90(3), 465-493. https://doi.org/10.2307/3761407

O’Donnell, K., Kistler, C. H., Cigelnik, E., \& Ploetz, R. C. (1998a). Multiple evolutionary origins of the fungus causing Panama disease of banana: concordant evidence from nuclear and mitochondrial gene genealogies. Proceedings of the National Academy of Sciences of the United States of America, 95(5), 2044-2049. https://doi.org/10.1073/pnas.95.5.2044

O’Donnell, K., Ward, T. J., Geiser, D. M., Kistler, H. C., \& Aoki, T. (2004). Genealogical concordance between the mating type locus and seven other nuclear genes supports formal recognition of nine phylogenetically distinct species within the Fusarium graminearum clade. Fungal Genetics and Biology, 41(6), 600-623. https://doi.org/10.1016/j.fgb.2004.03.003

Rangel-Castillo, E. A., Valadez-Moctezuma, E., \& Lozoya-Saldaña, H. (2017). Molecular characterization and pathogenesis of Fusarium associated to wheat yellowing. Revista Fitotecnia Mexicana, 40(4), 439-450.

Summerell, B. A., Leslie, J. F., Liew, E. C., Laurence, M. H., Bullock, S., Petrovic, T., . . . Burgess, L. W. (2011). Fusarium species associated with plants in Australia. Fungal Diversity, 46, 1-27. https://doi.org/10.1007/s13225-010-0075-8

Tamura, K., Stecher, G., Peterson, D., Filipski, A., \& Kumar, S. (2013). MEGA6: Molecular Evolutionary Genetics Analysis Version 6.0. Molecular Biology and Evolution, 30(12), 2725-2729. https://doi.org/10.1093/molbev/mst197

Taylor, J. W., Hann-Soden, C., Branco, S., Sylvain, I., \& Ellison, C. E. (2015). Clonal reproduction in fungi. Proceedings of the National Academy of Sciences of the United States of America, 112(29), 8901-8908. https://doi.org/10.1073/pnas.1503159112

Turgeon, G. B. (1998). Application of mating type gene technology to problems in fungal biology. Annual Review of Phytopathology, 36, 115-137. https://doi.org/10.1146/annurev.phyto.36.1.115

Turgeon, G. B., \& Yoder, O. C. (2000). Proposed nomenclature for mating type genes of filamentous ascomycetes. Fungal Genetics and Biology, 31, 1-5. https://doi.org/10.1006/fgbi.2000.1227

Waalwijk, C., Keszthelyi, A., van der Lee, T., Jeney, A., de Vries, I., Kerenyi, Z., . . . Hornok, L. (2006). Mating type loci in Fusarium: structure and function. Mycotoxin Research, 22, 54-60. https://doi.org/10.1007/BF02954558

Waalwijk, C., Vanheule, A., Audenaert, K., Zhang, H., Warris, S., van de Geest, H., \& van der Lee, T. (2017). Fusarium in the age of genomics. Tropical Plant Pathology, 42, 184189. https://doi.org/10.1007/s40858-017-0128-6

Wik, L., Karlsson, M., \& Johannesson, H. (2008). The evolutionary trajectory of the matingtype (MAT) genes in Neurospora relates to reproductive behavior of taxa. BMC Evolutionary Biology, 8, 109. https://doi.org/10.1186/1471-2148-8-109

Yun, S.-H., Arie, T., Kaneko, I., Yoder, O. C., \& Turgeon, G. B. (2000). Molecular organization of mating type loci in heterothallic, homothallic, and asexual Gibberella/Fusarium species. Fungal Genetics and Biology, 31(1), 7-20. https://doi.org/10.1006/fgbi.2000.1226 
Supplementary Table S1. Isolates obtained and sequenced in this study.

\begin{tabular}{|c|c|c|c|c|c|c|c|c|}
\hline No. & Isolate & $\begin{array}{l}\text { Mating } \\
\text { type }\end{array}$ & $\begin{array}{l}\text { MAT Seq } \\
\text { ID }\end{array}$ & $\begin{array}{l}\text { EF1- } \alpha \text { Seq } \\
\text { ID }\end{array}$ & SSU Seq ID & Specie name & Crop & Origin \\
\hline 1 & $\mathrm{~T} 1.13$ & MAT1-1 & KT876060.1 & KU508368.1 & NS & Fusarium thapsinum & Wheat & Penjamo, Gto. \\
\hline 2 & E8.2 & MAT1-1 & KT876058.1 & NS & NS & Fusarium thapsinum & Wheat & Salamanca, Gto. \\
\hline 3 & E8.3 & MAT1-1 & KT876059.1 & NS & NS & Fusarium thapsinum & Wheat & Salamanca, Gto. \\
\hline 4 & T6.10 & $M A T 1-1$ & KT876061.1 & KU508367.1 & KX218409.1 & Fusarium thapsinum & Wheat & Penjamo, Gto. \\
\hline 5 & $\mathrm{R} 1.6$ & MAT1-1 & KT587265.1 & NS & NS & Fusarium nygamai & Wheat & Penjamo, Gto. \\
\hline 6 & $\mathrm{~T} 7.2$ & MAT1-1 & KT876057.1 & KU508372.1 & NS & Fusarium nygamai & Wheat & Abasolo,Gto. \\
\hline 7 & $\mathrm{~T} 1.3$ & MAT1-1 & KT587267.1 & NS & NS & Fusarium nygamai & Wheat & Penjamo, Gto. \\
\hline 8 & E5.7 & MAT1-1 & KT587264.1 & NS & NS & $\begin{array}{l}\text { Fusarium } \\
\text { verticillioides }\end{array}$ & Wheat & Penjamo, Gto \\
\hline 9 & $\mathrm{~T} 2.1$ & MAT1-1 & KT587263.1 & KU508360.1 & KX218395.1 & $\begin{array}{l}\text { Fusarium } \\
\text { verticillioides }\end{array}$ & Wheat & Penjamo, Gto \\
\hline 10 & R6.6 & MAT1-1 & KT876063.1 & NS & KX218407.1 & Fusarium oxysporum & Wheat & Penjamo, Gto. \\
\hline 11 & T8.2 & MAT1-1 & KT876062.1 & NS & KX218406.1 & Fusarium oxysporum & Wheat & Salamanca, Gto. \\
\hline 12 & F6 & MAT1-1 & EU841016.1 & KC113013.1 & NS & Fusarium oxysporum & Chickpea & Singuio, Mich. \\
\hline 13 & F7 & MAT1-1 & EU841018.1 & KC113031.1 & NS & Fusarium oxysporum & Chickpea & Singuio, Mich. \\
\hline 14 & F10 & MAT1-1 & EU841027.1 & EU091043.1 & EU418431.1 & Fusarium oxysporum & Chickpea & Singuio, Mich. \\
\hline 15 & F12 & MAT1-1 & EU841019.1 & KC113014.1 & NS & Fusarium oxysporum & Chickpea & La purisima, Mich. \\
\hline 16 & F13 & MAT1-1 & EU841020.1 & KC113015.1 & NS & Fusarium oxysporum & Chickpea & La purisima, Mich. \\
\hline 17 & F19 & MAT1-1 & EU841015.1 & KC113030.1 & NS & Fusarium oxysporum & Chickpea & INIFAP, Mich. \\
\hline 18 & $\mathrm{~F} 21$ & MAT1-1 & EU841021.1 & EU091045.1 & NS & Fusarium oxysporum & Chickpea & El Calvario, Mich. \\
\hline 19 & F23 & MAT1-1 & EU841022.1 & EU091047.1 & NS & Fusarium oxysporum & Chickpea & Morelia, Mich. \\
\hline 20 & $\mathrm{~F} 24$ & MAT1-1 & EU841023.1 & KC113016.1 & NS & Fusarium oxysporum & Chickpea & Morelia, Mich. \\
\hline 21 & F26 & MAT1-1 & EU841024.1 & EU091048.1 & NS & Fusarium oxysporum & Chickpea & Morelia, Mich. \\
\hline 22 & F29 & MAT1-1 & EU841025.1 & KC113018.1 & NS & Fusarium oxysporum & Chickpea & Morelia, Mich. \\
\hline 23 & F30 & MAT1-1 & KT876064.1 & KC113019.1 & NS & Fusarium oxysporum & Chickpea & Morelia, Mich. \\
\hline 24 & F31 & MAT1-1 & EU841026.1 & EU091049.1 & NS & Fusarium oxysporum & Chickpea & Morelia, Mich. \\
\hline 25 & F35 & MAT1-1 & EU841014.1 & EU091050.1 & NS & Fusarium oxysporum & Chickpea & Cuitzeo, Mich. \\
\hline 26 & F36 & MAT1-1 & EU841013.1 & NS & NS & Fusarium oxysporum & Chickpea & Cuitzeo, Mich. \\
\hline 27 & F37 & MAT1-1 & EU841012.1 & EU091051.1 & NS & Fusarium oxysporum & Chickpea & Cuitzeo, Mich. \\
\hline 28 & F38 & MAT1-1 & EU841011.1 & EU091052.1 & NS & Fusarium oxysporum & Chickpea & Cuitzeo, Mich. \\
\hline 29 & $\mathrm{~F} 41$ & MAT1-1 & EU841010.1 & EU091053.1 & NS & Fusarium oxysporum & Chickpea & Puquichapio, Gto. \\
\hline 30 & F44 & MAT1-1 & EU841028.1 & EU091056.1 & EU418432.1 & Fusarium oxysporum & Chickpea & Valle de Santiago, Gto. \\
\hline 31 & F47 & MAT1-1 & EU841009.1 & EU091057.1 & NS & Fusarium oxysporum & Chickpea & Valle de Santiago, Gto. \\
\hline 32 & F54 & MAT1-1 & KT876066.1 & KC113023.1 & NS & Fusarium oxysporum & Chickpea & Yuriria, Gto. \\
\hline 33 & F62 & MAT1-1 & KT876065.1 & EU091064.1 & NS & Fusarium oxysporum & Chickpea & Salvatierra, Gto. \\
\hline 34 & F67 & MAT1-1 & EU841017.1 & EU091065.1 & NS & Fusarium oxysporum & Chickpea & Celaya, Gto. \\
\hline 35 & F68 & $M A T 1-1$ & EU841008.1 & EU091066.1 & NS & Fusarium oxysporum & Chickpea & Celaya, Gto. \\
\hline 36 & F70 & $M A T 1-1$ & EU841007.1 & KC113026.1 & NS & Fusarium oxysporum & Chickpea & Irapuato, Gto. \\
\hline 37 & F71 & MAT1-1 & EU841006.1 & EU091067.1 & NS & Fusarium oxysporum & Chickpea & Irapuato, Gto. \\
\hline 38 & F72 & MAT1-1 & EU841029.1 & EU091068.1 & NS & Fusarium oxysporum & Chickpea & Irapuato, Gto. \\
\hline
\end{tabular}




\begin{tabular}{|c|c|c|c|c|c|c|c|c|}
\hline No. & Isolate & $\begin{array}{l}\text { Mating } \\
\text { type }\end{array}$ & $\begin{array}{l}\text { MAT Seq } \\
\text { ID }\end{array}$ & $\begin{array}{l}\text { EF1- } \alpha \text { Seq } \\
\text { ID }\end{array}$ & SSU Seq ID & Specie name & Crop & Origin \\
\hline 39 & F73 & MAT1-1 & EU841030.1 & KC113029.1 & NS & Fusarium oxysporum & Chickpea & Juventino Rosas, Gto. \\
\hline 40 & F75 & $M A T 1-1$ & EU841031.1 & KC113028.1 & NS & Fusarium oxysporum & Chickpea & Apaseo el Grande, Gto. \\
\hline 41 & $\mathrm{~F} 2$ & MAT1-1 & NS & EU091074.1 & NS & Fusarium oxysporum & Chickpea & El Calvario, Mich. \\
\hline 42 & F3 & MAT1-1 & NS & $\mathrm{KC} 113012.1$ & NS & Fusarium oxysporum & Chickpea & El Calvario, Mich. \\
\hline 43 & F9 & $M A T 1-1$ & NS & EU091042.1 & NS & Fusarium oxysporum & Chickpea & Singuio, Mich. \\
\hline 44 & F15 & MAT1-1 & NS & EU091044.1 & NS & Fusarium oxysporum & Chickpea & La purisima, Mich. \\
\hline 45 & F28 & MAT1-1 & NS & KC113017.1 & NS & Fusarium oxysporum & Chickpea & Morelia, Mich. \\
\hline 46 & F34 & MAT1-1 & NS & $\mathrm{KC} 113021.1$ & NS & Fusarium oxysporum & Chickpea & Morelia, Mich. \\
\hline 47 & $\mathrm{~F} 42$ & MAT1-1 & NS & EU091054.1 & NS & Fusarium oxysporum & Chickpea & Puquichapio, Gto. \\
\hline 48 & F52 & MAT1-1 & NS & KC113022.1 & NS & Fusarium oxysporum & Chickpea & Yuriria, Gto. \\
\hline 49 & F55 & MAT1-1 & NS & EU091060.1 & NS & Fusarium oxysporum & Chickpea & Yuriria, Gto. \\
\hline 50 & F63 & MAT1-1 & NS & KC113024.1 & NS & Fusarium oxysporum & Chickpea & Salvatierra, Gto. \\
\hline 51 & F76 & MAT1-1 & NS & KC113036.1 & NS & Fusarium oxysporum & Chickpea & Cortazar, Gto. \\
\hline 52 & F77 & MAT1-1 & NS & $\mathrm{KC} 113025.1$ & NS & Fusarium oxysporum & Chickpea & Yuriria, Gto. \\
\hline 53 & $\mathrm{~T} 1.8$ & MAT1-1 & NS & KU508373.1 & KX218401.1 & Fusarium oxysporum & Wheat & Penjamo, Gto \\
\hline 54 & $\mathrm{~T} 1.17$ & MAT1-1 & NS & KU508371.1 & NS & Fusarium oxysporum & Wheat & Penjamo, Gto. \\
\hline 55 & $\mathrm{R} 4.2$ & MAT1-1 & NS & KU508370.1 & NS & Fusarium oxysporum & Wheat & Penjamo, Gto. \\
\hline 56 & R6.7 & MAT1-1 & NS & KU508359.1 & NS & Fusarium oxysporum & Wheat & Penjamo, Gto. \\
\hline 57 & $\mathrm{R} 1.2$ & $M A T 1-1$ & NS & NS & NS & $\mathrm{NI}$ & Wheat & Penjamo, Gto. \\
\hline 58 & $\mathrm{R} 1.3$ & MAT1-1 & NS & NS & NS & NI & Wheat & Penjamo, Gto \\
\hline 59 & $\mathrm{R} 1.9$ & MAT1-1 & NS & NS & NS & NI & Wheat & Penjamo, Gto. \\
\hline 60 & $\mathrm{R} 2.1$ & MAT1-1 & NS & NS & NS & $\mathrm{NI}$ & Wheat & Penjamo, Gto \\
\hline 61 & $\mathrm{R} 5.3$ & MAT1-1 & NS & NS & NS & $\mathrm{NI}$ & Wheat & Penjamo, Gto \\
\hline 62 & $\mathrm{R} 5.6$ & MAT1-1 & NS & NS & NS & NI & Wheat & Penjamo, Gto. \\
\hline 63 & $\mathrm{R} 7.2$ & MAT1-1 & NS & NS & NS & $\mathrm{NI}$ & Wheat & Abasolo, Gto. \\
\hline 64 & E5.5 & MAT1-1 & NS & NS & NS & NI & Wheat & Penjamo, Gto. \\
\hline 65 & T6.2 & MAT1-1 & NS & NS & NS & $\mathrm{NI}$ & Wheat & Penjamo, Gto. \\
\hline 66 & T8.3-1 & MAT1-1 & NS & NS & NS & NI & Wheat & Salamanca, Gto. \\
\hline 67 & $\mathrm{R} 3.3$ & $M A T 1-2$ & KT883572.1 & NS & KX218396.1 & Fusarium nygamai & Wheat & Penjamo, Gto \\
\hline 68 & $\mathrm{R} 6.2$ & $M A T 1-2$ & KT883574.1 & NS & NS & Fusarium nygamai & Wheat & Penjamo, Gto. \\
\hline 69 & R6.11 & MAT1-2 & KT883576.1 & NS & NS & Fusarium nygamai & Wheat & Penjamo, Gto. \\
\hline 70 & $\mathrm{~T} 1.5$ & $M A T 1-2$ & KT883577.1 & NS & NS & Fusarium nygamai & Wheat & Penjamo, Gto. \\
\hline 71 & $\mathrm{~T} 1.14$ & $M A T 1-2$ & KT883575.1 & NS & NS & Fusarium nygamai & Wheat & Penjamo, Gto. \\
\hline 72 & $\mathrm{~T} 3.3$ & MAT1-2 & KT883578.1 & KU508364.1 & NS & Fusarium nygamai & Wheat & Penjamo, Gto \\
\hline 73 & $\mathrm{R} 3.2$ & $M A T 1-2$ & KT883579.1 & NS & NS & Fusarium oxysporum & Wheat & Penjamo, Gto \\
\hline 74 & R5.1 & $M A T 1-2$ & KT883580.1 & NS & KX218405.1 & Fusarium oxysporum & Wheat & Penjamo, Gto \\
\hline 75 & F8 & $M A T 1-2$ & EU841044.1 & EU091041.1 & NS & Fusarium oxysporum & Chickpea & Singuio, Mich. \\
\hline 76 & F29S & MAT1-2 & EU841046.1 & NS & NS & Fusarium oxysporum & Chickpea & Sinaloa \\
\hline 77 & F33 & MAT1-2 & EU841045.1 & $\mathrm{KC} 113035.1$ & NS & Fusarium oxysporum & Chickpea & Morelia, Mich. \\
\hline 78 & F35S & $M A T 1-2$ & EU841041.1 & NS & NS & Fusarium oxysporum & Chickpea & Sinaloa \\
\hline 79 & F36S & MAT1-2 & EU841040.1 & NS & NS & Fusarium oxysporum & Chickpea & Sinaloa \\
\hline
\end{tabular}




\begin{tabular}{|c|c|c|c|c|c|c|c|c|}
\hline No. & Isolate & $\begin{array}{l}\text { Mating } \\
\text { type }\end{array}$ & $\begin{array}{l}\text { MAT Seq } \\
\text { ID }\end{array}$ & $\begin{array}{l}\text { EF1- } \alpha \text { Seq } \\
\text { ID }\end{array}$ & SSU Seq ID & Specie name & Crop & Origin \\
\hline 80 & $\mathrm{~F} 45$ & $M A T 1-2$ & EU841039.1 & KC113032.1 & NS & Fusarium oxysporum & Chickpea & Valle de Santiago, Gto. \\
\hline 81 & F46S & $M A T 1-2$ & EU841043.1 & NS & NS & Fusarium oxysporum & Chickpea & Sinaloa \\
\hline 82 & F48 & MAT1-2 & EU841047.1 & EU091058.1 & NS & Fusarium oxysporum & Chickpea & Valle de Santiago, Gto. \\
\hline 83 & F50 & $M A T 1-2$ & EU841036.1 & KC113033.1 & NS & Fusarium oxysporum & Chickpea & Yuriria, Gto. \\
\hline 84 & F53 & $M A T 1-2$ & EU841037.1 & EU091059.1 & NS & Fusarium oxysporum & Chickpea & Yuriria, Gto. \\
\hline 85 & F57 & MAT1-2 & EU841035.1 & EU091061.1 & NS & Fusarium oxysporum & Chickpea & Yuriria, Gto. \\
\hline 86 & F58 & MAT1-2 & EU841048.1 & EU091062.1 & NS & Fusarium oxysporum & Chickpea & Salvatierra, Gto. \\
\hline 87 & F59 & $M A T 1-2$ & EU841034.1 & $\mathrm{KC} 113040.1$ & NS & Fusarium oxysporum & Chickpea & Salvatierra, Gto. \\
\hline 88 & F60 & $M A T 1-2$ & EU841049.1 & EU091063.1 & NS & Fusarium oxysporum & Chickpea & Salvatierra, Gto. \\
\hline 89 & F61 & MAT1-2 & EU841038.1 & KC113041.1 & NS & Fusarium oxysporum & Chickpea & Salvatierra, Gto. \\
\hline 90 & F65 & $M A T 1-2$ & EU841042.1 & EU091070.1 & NS & Fusarium oxysporum & Chickpea & Salvatierra, Gto. \\
\hline 91 & F66 & $M A T 1-2$ & EU841032.1 & KC113027.1 & NS & Fusarium oxysporum & Chickpea & Celaya, Gto. \\
\hline 92 & F74 & MAT1-2 & EU841033.1 & EU091069.1 & NS & Fusarium oxysporum & Chickpea & Villagran, Gto. \\
\hline 93 & $\mathrm{R} 1.8$ & $M A T 1-2$ & NS & NS & KX218397.1 & Fusarium oxysporum & Wheat & Penjamo, Gto. \\
\hline 94 & $\mathrm{R} 4.2$ & MAT1-2 & NS & KU508370.1 & NS & Fusarium oxysporum & Wheat & Penjamo, Gto. \\
\hline 95 & $\mathrm{~T} 1.6$ & $M A T 1-2$ & NS & NS & KX218398.1 & Fusarium oxysporum & Wheat & Penjamo, Gto. \\
\hline 96 & $\mathrm{~T} 1.10$ & $M A T 1-2$ & NS & KU508369.1 & NS & Fusarium oxysporum & Wheat & Penjamo, Gto. \\
\hline 97 & $\mathrm{~T} 1.5$ & $M A T 1-2$ & KT883577.1 & NS & NS & Fusarium nygamai & Wheat & Abasolo, Gto. \\
\hline 98 & $\mathrm{R} 1.4$ & $M A T 1-2$ & NS & NS & NS & $\mathrm{NI}$ & Wheat & Penjamo, Gto. \\
\hline 99 & $\mathrm{R} 1.5$ & $M A T 1-2$ & NS & NS & KX218404.1 & Fusarium sp. & Wheat & Penjamo, Gto. \\
\hline 100 & $\mathrm{R} 2.2$ & $M A T 1-2$ & NS & NS & NS & NI & Wheat & Penjamo, Gto \\
\hline 101 & R6.10 & $M A T 1-2$ & NS & KU508363.1 & NS & Fusarium sp. & Wheat & Penjamo, Gto. \\
\hline 102 & $\mathrm{~T} 1.2$ & $M A T 1-2$ & NS & KU508365.1 & KX218402.1 & Fusarium sp. & Wheat & Penjamo, Gto. \\
\hline 103 & $\mathrm{~T} 4.1$ & $M A T 1-2$ & NS & NS & NS & NI & Wheat & Penjamo, Gto. \\
\hline 104 & $\mathrm{~T} 7.1$ & $M A T 1-2$ & NS & NS & NS & $\mathrm{NI}$ & Wheat & Penjamo, Gto. \\
\hline 105 & $\mathrm{~T} 1.11$ & $M A T 1-2$ & NS & NS & NS & NI & Wheat & Penjamo, Gto. \\
\hline 106 & $\mathrm{~T} 1.15$ & $M A T 1-2$ & NS & KU508361.1 & KX218399.1 & Fusarium sp. & Wheat & Penjamo, Gto. \\
\hline 107 & $\mathrm{~T} 1.16$ & $M A T 1-2$ & NS & NS & NS & NI & Wheat & Penjamo, Gto. \\
\hline 108 & $\mathrm{~T} 3.1$ & $M A T 1-2$ & NS & NS & NS & NI & Wheat & Penjamo, Gto \\
\hline 109 & T6.1 & $M A T 1-2$ & NS & KU508366.1 & NS & Fusarium sp. & Wheat & Penjamo, Gto. \\
\hline 110 & $\mathrm{~T} 7.3$ & MAT1-2 & NS & NS & NS & NI & Wheat & Abasolo, Gto. \\
\hline
\end{tabular}

EF1- $\alpha$ : translation elongation factor 1- $\alpha$

SSU: small subunit ribosomal RNA

NS: Not sequenced

NI: Not identified

Gto.: State of Guanajuato

Mich.: State of Michoacán 